\title{
MODULATION OF PHENOLICS SUBSTANCES AND ANTIOXIDANT ACTIVITY IN MANDAI CEM PEDAK BY UNSALTED SPONTANEOUS AND Lactobacillus casei INDUCED FERMENTATION
}

\author{
[Modulasi Komponen Fenolik dan Aktivitas Antioksidan pada Mandai Cempedak yang \\ Difermentasi Spontan tanpa Garam dan Diinduksi Lactobacillus casei]
}

\author{
Anton Rahmadi*, Kartika Sari, Frio Handayani, Yuliani, and Sulistyo Prabowo \\ Department of Agricultural Products Technology, Faculty of Agriculture, Mulawarman Unive rsity, Samarinda \\ Received April $2^{\text {nd }} 2018 /$ Accepted February $27^{\text {th }} 2019$
}

\begin{abstract}
Cempedak (Artocarpus champeden) is a tropical fruit whose inner-skin contains high polyphenolicbased antioxidant. Traditionally, the inner-skin is soaked in brine to induce spontaneous lactic acid bacteria (LAB) fermentation. This research aimed to investigate the changes of polyphenolics substances and antioxidant activity during the course of spontaneous and Lactobacillus case $i$ induced fermented at optimum $\left(37^{\circ} \mathrm{C}\right)$ and sub-optimum $\left(8^{\circ} \mathrm{C}\right)$ temperatures. Phenolic substances were spectrophotometrically measured with gallic acid (GAE), tannic acid (TAE), and catechin (CE) as the standards for the respective groups. The $50 \%$ maximum inhibitory concentration $\left(\mathrm{IC}_{50}\right)$ for DPPH reduction was measured. A thin layer chromatography (TLC) using different solvents was utilized to qualitatively show differences of substances extracted from the unfermented and fermented mandai cempedak. The retention factor (Rf) values for TLC spots were measured after the plates were exposed under 366 and $254 \mathrm{~nm}$ of UV lamp. Fermentation increased phenolic substances release from the inner skin of cempedak which positively modulated the potential antioxidant activity. Sub-optimum temperature fermentation reduced total phenolic-based antioxidant. Ethyl acetate or combinations of $n$-hexane and ethyl acetate gave better separation in TLC plate. Differences in stain patterns were exhibited by mandai cempedak before and after $L$. casei induced fermentation. In summary, L. casei induced fermentation was more effective at optimum temperature to increase phytochemical substances of mandai cempedak, while spontaneous fermentation showed to be more effective after 11 and 13 days at sub-optimum temperature.
\end{abstract}

Keywords: antioxidant activity, fermentation, mandai cempedak, phytochemicals, TLC

\begin{abstract}
ABSTRAK
Cempedak (Artocarpus champeden) adalah buah tropis yang kulit bagian dalamnya mengandung antioksidan berbasis polifenol dengan konsentrasi yang cukup tinggi. Secara tradisional, kulit bagian da lam direndam dalam airgaram untuk menginduksi fermentasi spontan bakteri asam laktat (LAB). Peneli tian ini bertujuan untuk mengetahui perubahan komponen polifenolik dan aktivitas antioksidan selama fermentasi spontan dan terinduksi L. casei pada kondisi optimum $\left(37^{\circ} \mathrm{C}\right)$ dan sub optimum $\left(8^{\circ} \mathrm{C}\right)$. Senyawasenyawa fenolik diukur secara spektrofotometri dengan asam gallic (GAE), asam tanat (TAE), dan katekin (CE) sebagai standar. Konsentrasi penghambatan setengah dari maksimal $\left({ }^{(} C_{50}\right)$ untuk reduksi DPPH diukur secara spektrofotometri. Kromatografi lapis tipis tipis (TLC) digunakan untuk secara kualitatif menun jukkan perbedaan senyawa-senyawa yang diekstraksi dari mandai cempedak yang tidak difermentasi dan difermentasi dengan pelarut yang berbeda. Nilai faktor retensi (Rf) diukur untuk masing-masing senyawa yang berhasil dipisahkan di bawah sinar UV dengan panjang gelombang 366 dan $254 \mathrm{~nm}$. Fermentasi meningkatkan pelepasan zat fenolik dari matriks buah yang secara positif memodulasi aktivitas antioksidan potensial. Fermentasi suhu suboptimal mengurangi total antioksidan berbasis fenol. Etil asetat atau kom binasi $n$-heksana dan etil asetatmemberikan pemisahan yang lebih baik pada pelat KLT. Perbedaan pola noda diperlihatk an dari mandai cempedak sebelum fermentasi dan setelah fermentasi dengan induksi $L$. casei. Sebagai kesimpulan, L. casei menginduksi fermentasi lebih efektif pada suhu optimal, sedangkan kultur spontan lebih efektif setelah 11 dan 13 hari pada fermentasi sub optimum.
\end{abstract}

Kata kunci: aktivitas antioksidan, fermentasi, fitokimia, mandai, TLC

${ }^{*}$ Coressponding Author:

Email: arahmadi@unmul.ac.id 


\section{INTRODUCTION}

Cempedak fruit (Artocarpus integer (Thunb.) Merr.) becomes a functional food source cultivated and easily obtained in Kalimantan. The appearance of the fruit is in resemblance to jackfruit, but has a stronger and unique aroma. The inner-skin is prevalently processed into fermented product called mandai cempedak. Bakar et al. (2015) reported that cempedak skin contains total phenolics, flavonoids, carotenoids, and antioxidant activity that are higher in concentrations than those in the flesh and seeds. Mandai cempedak fermentation is accomplished by soaking the product in brine for a certain period of time. To be effective and to reduce contamination, spontaneous fermentation uses high concentration of salt of approximately at $15-25 \% \mathrm{w} / \mathrm{v}$ (Rhee et al., 2011). However, the addition of salt may limit consumer acceptance of the product and may negatively affect consumer health. Furthermore, the use of salt in spontaneous fermentation of mandai cempedak may reduce the potential utilization of derivative products in the food industry. The use of low concentrations of salt or no salt added may contribute to reduce the health risk of high-salt (Nur, 2009). Hygienic processing was proven to reduce the requirement of salt induced spontaneous LAB fermentation as exhibited by Rahmadi et al. (2017).

Lactobacillus casei was selected as the pilot culture for induced mandai cempedak fermentation due to the availability in the form of commercial culture. Further, $L$. casei is one of the most studied $\mathrm{LAB}$. Therefore, the performance of the LAB in mandai cempedak can be better related to fermentation profiles of $L$. casei reported in other research. Rahmadi et al. (2017) reported that isolate of $L$. casei may be used to induce fermentation in cempedak mandai.

To produce a derivative product, i.e. local flavor, that is also rich in antioxidants, fermentation and further processing of mandai cempedak are in need to be optimized with the help of starter culture and hygienic fermentation. The rate of growth of $L$. casei in this induced fermentation is almost equal to the growth rate of spontaneous cultures that are predominantly conducted by L. plantarum and Leuconostoc (Rahmadi et al., 2017; Emmawati, 2015). The sub-optimal fermentation temperature resulted in preferred organoleptic properties of the mandai cempedak. General increase of the panelist's acceptance was due to higher $\mathrm{pH}$ of the fermented mandai cempedak. In derived product, the polyphenol substances of the mandai cempedak flour can be maintained when the product was dried at $50^{\circ} \mathrm{C}$ (Rahmadi et al., 2018).

Fermentation plays a role in the release of phenolic substances from food matrices, while LAB may produce simple hydroxyl $(-\mathrm{OH})$ metabolites, i.e. phe- nyllactic acid, that may be detected as total phenolic (Valerio et al., 2016). Further, the contents of phytochemical compounds are directly related to the antioxidant capacity (Li et al., 2009; Mihai et al., 2011). There is a need of examining phenolic based antioxidant activity to further prove that starter culture in slow and fast fermentation gives better choices of technology that can be commercially applied. This study aims to determine changes in phenolic compounds and DPPH-based antioxidant capacity during spontaneous or induced fermentation with $L$. casei at optimum $\left(37^{\circ} \mathrm{C}\right)$ and sub optimum $\left(8^{\circ} \mathrm{C}\right)$ temperatures.

\section{MATERIALS AND METHODS}

\section{Materials}

The raw materials used in this study were mature cempedak fruit obtained from traders in the market around Samarinda, East Kalimantan, Indonesia. Lactobacillus casei was isolated from Yakult ${ }^{\circledR}$ and cultured in skim milk preparation medium.

\section{Research design}

Quantitative study with quasi experimental design approach was utilized, consisting of two parts, namely a comparison between $L$. casei induced and spontaneous fermentations at different temperatures of 37 and $8^{\circ} \mathrm{C}$ for defined days of observations. Each observation was conducted in two replicates. Parameters observed in this study were total tannins, phenols, flavonoids and antioxidant activity. Retention factors (Rf) for TLC spots were measured after the plates were exposed under 366 and 254 nm of UV lamp.

\section{Mandai cempedak preparation}

The inner skin of the cempedak fruit was used after being sorted and cleansed. Processing of inner skin of cempedak fruit and induction of LAB for fermentation were conducted in accordance with procedure written in patent no. IDS000002032. Spontaneous fermentation was carried out in the same manner without the addition of starter culture of $L$. casei. For the incubation treatment at $37^{\circ} \mathrm{C}$, the mandai cempedak was observed daily until day 7 . For the sub-optimum temperature treatment at $8^{\circ} \mathrm{C}$, the mandai cempedak was observed every two day up to the $13^{\text {th }}$ day.

\section{Total phenols}

Total phenols were measured by modifying methods originally developed by Mu'nisa et al. (2012) and Nurhayati et al. (2012). As much as $0.3 \mathrm{~g}$ of ethanolic extract of mandai cempedak was carefully weighed and dissolved in $10 \mathrm{~mL}$ of ethanol (SmartLab, Indonesia) and distillated water (Soil Laborato- 
ry, Mulawarman University) at ratio of $1: 1$. About 0.2 $\mathrm{mL}$ of the extract solution was taken and added with $15.8 \mathrm{~mL}$ of distillated water and $1 \mathrm{~mL}$ of $50 \%(\mathrm{v} / \mathrm{v})$ of Folin-Ciocalteu (Sigma-Aldrich, Germany) reagents prepared in aqueous solution. The solution was allowed to stand for \pm 8 minutes and added with 3 $\mathrm{mL}$ of $5 \%(\mathrm{w} / \mathrm{v})$ of $\mathrm{Na}_{2} \mathrm{CO}_{3}$ (Sigma-Aldrich, Germany) prepared in aqueous solution. The solution was further allowed to stand for \pm 2 hours in a dark condition at room temperature $\left(28 \pm 2^{\circ} \mathrm{C}\right)$. The absorbance was measured at $725 \mathrm{~nm}$ of wavelength. The absorbance was plotted against the standard curve of gallic acid prepared in the same manner. Total phenols were expressed in $\mathrm{mg}$ equivalent of gallic acid per $\mathrm{kg}$ of dry weight.

\section{Total tannins}

A modified method from Malangngi et al. (2012) was performed to measure the total tannins. A total of $0.5 \mathrm{~g}$ of mandai cempedak was macerated with $10 \mathrm{~mL}$ of diethyl ether (Merck, Singapore) for 20 hours in a closed tube, then the sample was filtered with Whatman filter paper. The obtained residue was boiled with $100 \mathrm{~mL}$ of distillated water for 2 hours, then was cooled and filtered. The extracts obtained were added with distillated water until the extract volume reached $100 \mathrm{~mL}$. A total of $0.1 \mathrm{~mL}$ of the extract was added with $0.1 \mathrm{~mL}$ of $50 \%(\mathrm{v} / \mathrm{v})$ of FolinCiocalteu reagents prepared in aqueous solution and was vortexed with vortex mixer. The sample was added with $2 \mathrm{~mL}$ of $5 \%(\mathrm{w} / \mathrm{v})$ of $\mathrm{Na}_{2} \mathrm{CO}_{3}$ prepared in aqueous solution and was vortexed. The absorbance was measured at $760 \mathrm{~nm}$ of wavelength after incubation for $30 \mathrm{~min}$ at room temperature $\left(28 \pm 2^{\circ} \mathrm{C}\right)$. The readings were plotted against the standard curve of tannic acid (Sigma-Aldrich, Germany) prepared in the same manner. The total content of tannins was expressed in $\mathrm{mg}$ of tannic acid per $\mathrm{kg}$ of dried extract.

\section{Total flavonoids}

To measure total flavonoids, the method developed by Zou et al. (2004) was employed. A total of $1 \mathrm{mg}$ of the mandai cempedak extract was weighed and dissolved in $10 \mathrm{~mL}$ of $95 \%$ ethanol (SmartLab, Indonesia). Distillated water was added to the solution at $0.7 \mathrm{~mL}$. To each solution, $0.1 \mathrm{~mL}$ of $5 \% \mathrm{NaNO}_{2}$ (Sigma-Aldrich, Germany) prepared in aqueous solution was added. After being stored for 5 minutes at room temperature, the sample was added with 0.1 $\mathrm{mL}$ of $10 \% \mathrm{AlCl}_{3}$ (Sigma-Aldrich, Germany) prepared in aqueous solution. After 6 minutes, $0.5 \mathrm{~mL}$ of $1 \mathrm{M}$ $\mathrm{NaOH}$ (Merck, USA) was added. All ingredients were mixed evenly and incubated for 10 minutes at room temperature. The absorbance was measured at a wavelength of $510 \mathrm{~nm}$ with $1 \mathrm{~mL}$ sample was replaced with $1 \mathrm{~mL}$ of $95 \%$ ethanol solvent. The results obtained were plotted against the standard ca- techin curve (Sigma-Aldrich, Germany) prepared in the same way. Total flavonoid was expressed as $\mathrm{mg}$ of catechin equivalent per $\mathrm{kg}$ of dry weight of extract.

\section{Antioxidant activity}

The antioxidant activity test was performed by spectrophotometric method (Farhan et al., 2012) by calculating the inhibition of 2,2-diphenyl-1-picrylhydrazyl (DPPH) (Sigma-Aldrich, Germany) reduction. A total of $1 \mathrm{~mL}$ of diluted extract in ethanol was added to $1 \mathrm{~mL}$ of DPPH $(0.15 \mathrm{mM}$ in ethanol) and at the same time, a control consisting of $1 \mathrm{~mL} D P P H$ with $1 \mathrm{~mL}$ of ethanol was prepared. The solution was well mixed and then incubated in the dark at room temperature for 30 minutes. The absorbance was measured at $517 \mathrm{~nm}$. Vitamin $\mathrm{C}$ was used as a positive control and ethanol was used as a blank. The DPPH capability of the extract was calculated using equation 1:

$$
\begin{aligned}
& \% \text { antioxidant activity }= \\
& \frac{(\text { control absorbance - sample absorbance) }}{\text { control absorbance }} \times 100
\end{aligned}
$$$$
\text { equation (1) }
$$

where, the absorbance of the control was the absorption of DPPH + ethanol, the absorbance of the sample was the absorbance of the radical DPPH + sample.

The obtained data was presented with $\mathrm{IC}_{50}$ value, and the value was obtained from linear regressing \%-DPPH inhibition of sample compound (31.25; 62.5; 125; 250 and 500 ppm). The linear regression equation is calculated as in equation 2 and equation 3:

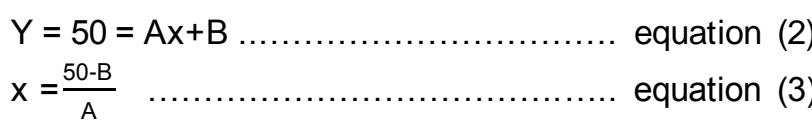

where, $Y$ is $I_{50}$ constant value (50), $A$ is The coefficient on the variable $x, B$ is constants and $x$ is $\mathrm{IC}_{50}$ value in ppm.

\section{TLC phytochemical profile of mandai cempedak} Cempedak powder sample before and after the $13^{\text {th }}$ day of the cold fermentation was prepared in ethanol solution according to method by Hanani (2014). Each sample was then spotted on a $10 \times 10$ $\mathrm{cm}$ of silica-based TLC plate (Merck, USA). Distance between spots was about 1 to $1.5 \mathrm{~cm}$. The spot was applied with a volume of 5-10 $\mu \mathrm{L}$. Spot was carefully planted to obtain as small diameter as possible. After the spotting was completed, the plate was left to dry in room temperature. The TLC plate was inserted into a chamber containing eluent in the pre- 
pared ratio of: (I) n-hexane (Merck, USA): ethyl acetate (Merck, USA) (1.4: 0.6), (II) n-hexane: ethyl acetate (0.6: 1.4), (III) chloroform (Merck, USA): methanol (Merck, USA) (1.6: 0.4), and (IV) ethyl acetate. Eluent was allowed to reach the limits of the creepage distance of the plate. The plates were removed and dried in the air at room temperature. The resulting spots were observed under ultraviolet lamps at wavelengths of $254 \mathrm{~nm}$ and $366 \mathrm{~nm}$.

\section{RESULTS AND DISCUSSION}

\section{Profile of phenolic substances and antioxidant activity}

Bakar et al. (2015) mentioned that the potential of total phenolic compounds is $21,000 \mathrm{mg} \mathrm{GAE} / \mathrm{kg}$ and the potential total flavonoid is $17,000 \mathrm{mg} \mathrm{CE} / \mathrm{kg}$ in the outer skin of the cempedak fruit. The flesh of cempedak fruit had potential total phenolic compounds amounted to $4,400 \mathrm{mg}$ GAE/ $\mathrm{kg}$ and total flavonoids amounted to $820 \mathrm{mg} \mathrm{CE} / \mathrm{kg}$. Total phenols of fermented mandai cempedak (Table 1) was in close similarity to that reported previously (Bakar et al., 2015). Total flavonoids throughout the fermentation duration were in increasing concentrations, despite the value was not as high as reported by Bakar et al. (2015). Of the four combinations of observed fermentation methods, the increase in these three phenolic parameters was consistent with the length of fermentation time (Table 1).

The total phenols increased between 0.5 and 2.5 folds higher in spontaneous and $L$. casei induced fermentation at all observed fermentation temperatures. Total tannins increased up to two folds higher, as well as total flavonoids. This caused the increase of antioxidant activity potential in fermented mandai cempedak (Table 1). Dajanta et al. (2013) reported that the total phenol content showed a higher increase, giving 217 and $859 \%$ in fermented black soybeans and yellow soybeans compared to unfermented ones. Nazarni et al. (2016) reported that jaruk tegarun extract, LAB fermented tegarun (Crataeva nurvala, Buch HAM) flower, had higher total tannins compared to the unfermented extract.

Antioxidant activity in fermentation showed an increase, this was indicated by decreasing $\mathrm{IC}_{50}$ value of antioxidant activity in mandai cempedak (Table 1). The smaller the value of $\mathrm{IC}_{50}$. the higher the antioxidant activity, as lesser concentration of the extract was required to inhibit DPPH reduction. This was consistent with Curiel et al (2015) that the inhibition of free radicals from Myrtus communis extract fermented with $L$. plantarum was higher than that of the non-fermented ones.

The concentration of phenol, tannin, flavonoid released from the inner skin of cempedak was influenced by the use of different fermentation temperatures (Table 1). As a general observation, the total tendency of phenol tannins, and flavonoids at a temperature of $8^{\circ} \mathrm{C}$ for seven days is approximately $50 \%$ of the concentrations of phenolic compounds released at $37^{\circ} \mathrm{C}$ during the same fermentation time. From this data, it can be concluded that the fermentation temperature affects the release of active compounds from the food matrix.

The temperature and power of hydrogen $(\mathrm{pH})$ may play a role in the release of phenolic substances in the fermentation of mandai cempedak. Generally, Lactobacillus is a genus of mesophilic bacteria, meaning that the metabolism works optimally at medium temperature, or in this study simulated at $37^{\circ} \mathrm{C}$ of fermentation temperature. This finding was similar to the previous research of Nur (2009), Rahmadi et al. (2013), Emmawati et al. (2015), and Nazarni et al. (2016) using spontaneous culture and starter $L$. plantarum to ferment mandai cempedak and jaruk tegarun.

Table 1. Phytochemicals and antioxidants of mandai cempedak during fermentation at 37 and $8^{\circ} \mathrm{C}$

\begin{tabular}{|c|c|c|c|c|c|c|c|c|}
\hline \multirow{2}{*}{ Day } & \multicolumn{2}{|c|}{$\begin{array}{l}\text { Total Phenol } \\
(\mathrm{mg} \mathrm{GAE} / \mathrm{kg})\end{array}$} & \multicolumn{2}{|c|}{$\begin{array}{l}\text { Total Tannin } \\
(\mathrm{mg} \mathrm{TAE} / \mathrm{kg}) \\
\end{array}$} & \multicolumn{2}{|c|}{$\begin{array}{c}\text { Total Flavonoid } \\
(\mathrm{mg} \mathrm{CE} / \mathrm{kg})\end{array}$} & \multicolumn{2}{|c|}{$\begin{array}{c}\text { Antioxidant activity } \\
\left(\mathrm{IC}_{50} \mathrm{ppm}\right)\end{array}$} \\
\hline & Spontaneous & $\begin{array}{l}\text { L. casei } \\
\text { Induced }\end{array}$ & Spontaneous & $\begin{array}{l}\text { L. casei } \\
\text { Induced }\end{array}$ & Spontaneous & $\begin{array}{l}\text { L. casei } \\
\text { Induced }\end{array}$ & Spontaneous & $\begin{array}{l}\text { L. casei } \\
\text { Induced }\end{array}$ \\
\hline \multicolumn{9}{|c|}{ Temperature of Fermentation: $37^{\circ} \mathrm{C}$} \\
\hline 1 & $1665 \pm 91 \mathrm{a}$ & $1751 \pm 64 a$ & $32.51 \pm 3.34 a$ & $36.69 \pm 0.51 \mathrm{a}$ & $886 \pm 0.30 \mathrm{a}$ & $9.252 \pm 0.817 a$ & $212.6 \pm 3.5 \mathrm{a}$ & $210.6 \pm 2.5 a$ \\
\hline 2 & $1883 \pm 59 a$ & $2297 \pm 73 a b$ & $46.33 \pm 3.86 b$ & $48.51 \pm 2.82 \mathrm{~b}$ & $10.0 \pm 0.64 \mathrm{~b}$ & $11.77 \pm 0.76 \mathrm{~b}$ & $200.4 \pm 3.1 \mathrm{~b}$ & $179.4 \pm 2.5 b$ \\
\hline 3 & $2213 \pm 27 b$ & $3615 \pm 286 \mathrm{bc}$ & $51.42 \pm 1.29 \mathrm{~b}$ & $49.42 \pm 7.20 \mathrm{~b}$ & $13.50 \pm 0.17 \mathrm{c}$ & $14.52 \pm 0.68 \mathrm{c}$ & $189.5 \pm 3.7 \mathrm{c}$ & $127.4 \pm 2.2 \mathrm{c}$ \\
\hline 4 & $2524 \pm 421 b c$ & $4013 \pm 304 \mathrm{c}$ & $51.60 \pm 6.17 \mathrm{~b}$ & $56.69 \pm 1.03 \mathrm{~b}$ & $14.91 \pm 0.97 \mathrm{c}$ & $16.38 \pm 0.51 d$ & $176.8 \pm 7.2 \mathrm{~d}$ & $122.0 \pm 3.4 \mathrm{~d}$ \\
\hline 5 & $3034 \pm 54 \mathrm{~cd}$ & $4366 \pm 494 d$ & $51.60 \pm 7.20 \mathrm{~b}$ & $56.33 \pm 4.11 \mathrm{~b}$ & $17.46 \pm 0.59 d$ & $21.29 \pm 0.17 \mathrm{e}$ & $157.5 \pm 1.9 \mathrm{e}$ & $93.19 \pm 0.17 \mathrm{e}$ \\
\hline 6 & $3564 \pm 132 \mathrm{~cd}$ & $4404 \pm 41 \mathrm{e}$ & $53.97 \pm 4.89 \mathrm{~b}$ & $52.15 \pm 2.31 \mathrm{bc}$ & $20.66 \pm 0.64 \mathrm{e}$ & $26.56 \pm 0.51 \mathrm{f}$ & $137.0 \pm 5.3 f$ & $65.88 \pm 0.73 f$ \\
\hline 7 & $3592 \pm 91 d$ & $4667 \pm 68 \mathrm{e}$ & $63.05 \pm 2.31 \mathrm{c}$ & $65.60 \pm 3.86 \mathrm{c}$ & $21.20 \pm 0.30 \mathrm{e}$ & $26.53 \pm 0.30 f$ & $130.9 \pm 4.6 f$ & $49.32 \pm 0.45 \mathrm{~g}$ \\
\hline \multicolumn{9}{|c|}{ Temperature of Fermentation: $8^{\circ} \mathrm{C}$} \\
\hline 1 & $1443 \pm 154 a$ & $1607 \pm 14 a$ & $39.42 \pm 1.29 a$ & $41.42 \pm 5.14 \mathrm{a}$ & $6 \pm 0.17 \mathrm{a}$ & $7.006 \pm 0.13 a$ & $205.0 \pm 0.16 \mathrm{a}$ & $217.8 \pm 16 a$ \\
\hline 3 & $1463 \pm 109 a$ & $1787 \pm 95 \mathrm{ab}$ & $39.42 \pm 0.26 a$ & $29.05 \pm 1.54 \mathrm{~b}$ & $7.545 \pm 0.21 \mathrm{~b}$ & $7.695 \pm 0.50 \mathrm{~b}$ & $180.3 \pm 0.47 b$ & $164.8 \pm 0.37 \mathrm{~b}$ \\
\hline 5 & $1636 \pm 36 a$ & $2040 \pm 9.07 \mathrm{bc}$ & $43.24 \pm 1.03 a$ & $37.78 \pm 3.09 a$ & $8.623 \pm 0.21 \mathrm{c}$ & $8.802 \pm 0.13 b c$ & $170.3 \pm 3.21 \mathrm{bc}$ & $133.5 \pm 1.88 \mathrm{c}$ \\
\hline 7 & $1687 \pm 45 b$ & $2204 \pm 59 \mathrm{~cd}$ & $37.24 \pm 3.34 a$ & $41.42 \pm 0.51 \mathrm{a}$ & $9.192 \pm 0.34 \mathrm{~cd}$ & $9.731 \pm 0.34 \mathrm{~cd}$ & $132.8 \pm 12 d$ & $111.9 \pm 5.30 \mathrm{~d}$ \\
\hline 9 & $1745 \pm 45 b$ & $2524 \pm 422 d$ & $40.69 \pm 0.51 a$ & $40.33 \pm 1.54 a$ & $9.521 \pm 0.13 d$ & $11.02 \pm 0.47 d$ & $112.4 \pm 0.39 \mathrm{e}$ & $95.07 \pm 1.29 \mathrm{e}$ \\
\hline 11 & $1828 \pm 18 \mathrm{~b}$ & $3034 \pm 54 \mathrm{e}$ & $40.87 \pm 3.86 a$ & $45.60 \pm 1.29 \mathrm{ac}$ & $9.820 \pm 0.04 \mathrm{de}$ & $13.68 \pm 0.93 \mathrm{e}$ & $88.62 \pm 2.71(\mathrm{f})$ & $94.29 \pm 1.45 \mathrm{e}$ \\
\hline 13 & $1860 \pm 109 b$ & $3592 \pm 91 f$ & $52.15 \pm 1.29 b$ & $43.42 \pm 2.82 \mathrm{c}$ & $11.44 \pm 0.55 \mathrm{e}$ & $13.59 \pm 0.64 e$ & $63.51 \pm 3.60(\mathrm{~g})$ & $87.24 \pm 1.66 \mathrm{e}$ \\
\hline & 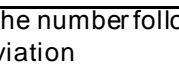 & & & & & & & \\
\hline
\end{tabular}


The metabolism of $L$. casei and L. plantarum in mandai cempedak tended to slow down at fermentation temperature of $8^{\circ} \mathrm{C}$, with the final value of $\mathrm{pH}$ ranging from 4.5 to 5.0 after 13 days, while at $37^{\circ} \mathrm{C}$ produced $\mathrm{pH}$ of 3.5 after 7 days (Rahmadi et al., 2017).

The use of specific species and strain of Lactobacillus may result in different concentration of metabolites, leading to dissimilar antioxidant activity (Park et al., 2015). The induction of $L$. casei in mandai cempedak fermentation consistently increased the total concentration of phenol, tannin, flavonoid at two different temperatures. However, the induction of $L$. casei was more effective in increasing antioxidant activity when the mandai cempedak was fermented at optimum temperature of $37^{\circ} \mathrm{C}$. Spontaneous fermentation at cold temperatures produced compounds capable of better inhibiting DPPH reduction after 11 days (Table 1). Rye bran that was fermented with lactic acid bacteria (L. lactis ssp. Lactis, L. plantarum, L. brevis, and L. helveticus) had higher antioxidant activity than spontaneous fermented buckwheat dough (Banu et al., 2010).

\section{Correlation of antioxidant activity and phenolic substance concentrations}

There is a relationship of the higher total phenols, total tannins, and flavonoids with the higher the antioxidant activity for both spontaneous and $L$. casei induced fermentation process (Table 2). Based on the table, it can be concluded that higher total content of phenols, tannins, and flavonoids during fermentation of mandai cempedak resulted in the higher the antioxidant activity indicated by the lower value of $\mathrm{IC}_{50}$.

The relationship between the total phenolic content and antioxidant activity is recognized in strong correlation. Li et al. (2009) also reported the antioxi- dant activities and phenolic contents of danggui (Angelicae sinensis) root had correlation coefficients (R) from 0.642 to 0.941 , with the average value of $R$ at 0.839 . Mihai et al. (2011) reported that the relationship between DPPH radical scavenging activity of propolis sample from Transylvania and the concentration of total polyphenols had a positive correlation with coefficient of multiple correlation $\left(R^{2}\right)$ at 0.8387 . Kusumowati et al. (2012) reported an association between antiradical and total phenolic content from the extracts of betel leaf (Piper bet/e), teak leaf (Tectona grandis) and katuk leaf (Sauropus androgynous). The positive correlation resulted in greater antiradical activity. Other study also examined strong relationship between inhibitory concentration $\left(\mathrm{IC}_{50}\right)$ of DPPH reduction and total phenolic and total flavonoid contents in tanjung fruit extract (Mimusops elengi), resulted in correlation coefficient valued (R) at 97 and $99 \%$, respectively (Perwiratami et al., 2014).

\section{TLC phytochemical profile of mandai cempedak}

There were different stain patterns for the separated phyto-compounds on each solvent used (Table $3)$. In the n-hexane:ethyl acetate (1.4:0.6) solvent, the fermented inner skin of cempedak contained compounds that were not present in the unfermented cempedak. In the eluent of n-hexane:ethyl acetate $(0.6: 1.4)$, there were compounds in the unfermented inner skin of cempedak that degraded after fermentation. The better separation when n-hexane mixes were employed indicated the tendency of higher hydrophobicity in some compounds. The better separation phenomenon was observed in ethyl acetate solvent as well. In chloroform:methanol (1.6:0.4) eluent, there were more concentrated compounds observed after the inner skin of cempedak was fermented.

Table 2. Correlation Analysis of Phenolic substance vs $\mathrm{IC}_{50}$ of inhibition of DPPH reduction

\begin{tabular}{|c|c|c|c|}
\hline Spontaneous Fermentation at $37^{\circ} \mathrm{C}$ & & & rvalue \\
\hline Total Phenol (mg GAE/Kg) & vS & $\mathrm{IC}_{50}$ of inhibition of DPPH reduction (ppm) & -0.998 \\
\hline Total Tannin (mg TAE $/ \mathrm{kg})$ & vs & $\mathrm{IC}_{50}$ of inhibition of DPPH reduction (ppm) & -0.853 \\
\hline Total Flavonoid (mg CE/kg) & vs & $\mathrm{IC}_{50}$ of inhibition of DPPH reduction (ppm) & -0.986 \\
\hline L. casei induced Fermentation at $37^{\circ} \mathrm{C}$ & & & rvalue \\
\hline Total Phenol (mg GAE/Kg) & vS & $\mathrm{IC}_{50}$ of inhibition of DPPH reduction (ppm) & -0.969 \\
\hline Total Tannin (mg TAE/kg) & vs & $\mathrm{IC}_{50}$ of inhibition of DPPH reduction (ppm) & -0.861 \\
\hline Total Flavonoid (mg CE/kg) & vs & $\mathrm{IC}_{50}$ of inhibition of DPPH reduction (ppm) & -0.969 \\
\hline Spontaneous Fermentation at $8^{\circ} \mathrm{C}$ & & & rvalue \\
\hline Total Phenol (mg GAE/Kg) & VS & $\mathrm{IC}_{50}$ of inhibition of DPPH reduction (ppm) & -0.964 \\
\hline Total Tannin (mg TAE/kg) & vs & $\mathrm{IC}_{50}$ of inhibition of DPPH reduction (ppm) & -0.585 \\
\hline Total Flavonoid (mg CE/kg) & vs & $\mathrm{IC}_{50}$ of inhibition of DPPH reduction (ppm) & -0.967 \\
\hline L. casei induced Fermentation at $8^{\circ} \mathrm{C}$ & & & r value \\
\hline Total Phenol (mg GAE/Kg) & VS & $\mathrm{IC}_{50}$ of inhibition of DPPH reduction (ppm) & -0.824 \\
\hline Total Tannin (mg TAE/kg) & vs & $\mathrm{IC}_{50}$ of inhibition of DPPH reduction (ppm) & -0.424 \\
\hline Total Flavonoid (mg CE/kg) & vs & $\mathrm{IC}_{50}$ of inhibition of DPPH reduction (ppm) & -0.868 \\
\hline
\end{tabular}


Table 3. Rf values of compounds in fermented and unfermented cempedak at 366 and $254 \mathrm{~nm}$

\begin{tabular}{|c|c|c|c|c|c|c|c|c|c|c|c|c|}
\hline \multirow{3}{*}{$\begin{array}{l}\text { Spot } \\
\text { No. }\end{array}$} & \multicolumn{3}{|c|}{$\begin{array}{l}\text { T. n-Hexane:Ethyl Acetate } \\
(1.4: 0.6)\end{array}$} & \multicolumn{3}{|c|}{$\begin{array}{l}\text { 1I. n-Hexane:Ethy Acetate } \\
(0.6: 1.4)\end{array}$} & \multicolumn{3}{|c|}{$\begin{array}{l}\text { TII. Chloroform:Methanol } \\
(1.6: 0.4)\end{array}$} & \multicolumn{3}{|c|}{ TV. Ethyl Acetate } \\
\hline & \multirow[b]{2}{*}{ Rf } & \multicolumn{2}{|c|}{ Spot Visibility } & \multirow[b]{2}{*}{ Rf } & \multicolumn{2}{|c|}{ Spot Visibility } & \multirow[b]{2}{*}{$\mathrm{Rf}$} & \multicolumn{2}{|c|}{ Spot Visibility } & \multirow[b]{2}{*}{$\mathrm{Rf}$} & \multicolumn{2}{|c|}{ Spot Visibility } \\
\hline & & $\begin{array}{c}\text { Before } \\
\text { Fermentation } \\
(\mathrm{A})\end{array}$ & $\begin{array}{c}\text { After } \\
\text { Fermentation } \\
\text { (B) }\end{array}$ & & $\begin{array}{c}\text { Before } \\
\text { Fermentation } \\
(\mathrm{A})\end{array}$ & $\begin{array}{c}\text { After } \\
\text { Fermentation } \\
\text { (B) }\end{array}$ & & $\begin{array}{c}\text { Before } \\
\text { Fermentation } \\
(\mathrm{A})\end{array}$ & $\begin{array}{c}\text { After } \\
\text { Fermentation } \\
\text { (B) }\end{array}$ & & $\begin{array}{c}\text { Before } \\
\text { Fermentation } \\
(\mathrm{A})\end{array}$ & $\begin{array}{c}\text { After } \\
\text { Fermentation } \\
\text { (B) }\end{array}$ \\
\hline \multicolumn{13}{|c|}{ UV lamp $\lambda=366 \mathrm{~nm}$} \\
\hline (a) & 0.06 & + & + & 0.04 & + & + & 0.34 & - & + & 0.04 & + & + \\
\hline (b) & 0.19 & - & + & 0.13 & + & + & 0.79 & - & + & 0.06 & + & + \\
\hline (c) & 0.30 & + & - & 0.25 & + & - & 0.87 & - & + & 0.09 & + & - \\
\hline (d) & 0.39 & - & + & 0.34 & + & + & 1.00 & + & + & 0.16 & + & + \\
\hline (e) & 0.46 & + & - & 0.44 & + & + & & & & 0.27 & + & - \\
\hline$(f)$ & 0.65 & + & + & 0.59 & + & - & & & & 0.34 & + & + \\
\hline (g) & 0.72 & + & + & 0.72 & + & - & & & & 0.50 & + & + \\
\hline (h) & 0.77 & + & + & 0.87 & + & - & & & & 0.58 & + & - \\
\hline (i) & 0.90 & + & + & 0.94 & + & + & & & & 0.72 & + & - \\
\hline (j) & 0.97 & + & + & & & & & & & 0.79 & + & + \\
\hline (k) & & & & & & & & & & 0.95 & + & + \\
\hline \multicolumn{13}{|c|}{ UV lamp $\lambda=254 \mathrm{~nm}$} \\
\hline (a) & 0.06 & + & + & 0.05 & + & + & 0.06 & - & + & 0.09 & + & + \\
\hline (b) & 0.20 & - & + & 0.13 & + & + & 0.13 & - & + & 0.16 & + & + \\
\hline (c) & 0.37 & + & - & 0.32 & + & - & 0.32 & - & + & 0.42 & + & - \\
\hline (d) & 0.66 & - & + & 0.43 & + & + & 0.97 & + & + & 0.56 & + & + \\
\hline (e) & 0.71 & + & - & 0.92 & + & + & & & & 0.97 & + & - \\
\hline$(f)$ & 0.77 & + & + & 0.98 & + & - & & & & & & \\
\hline (g) & 0.77 & + & + & & & & & & & & & \\
\hline (h) & 0.96 & + & + & & & & & & & & & \\
\hline
\end{tabular}
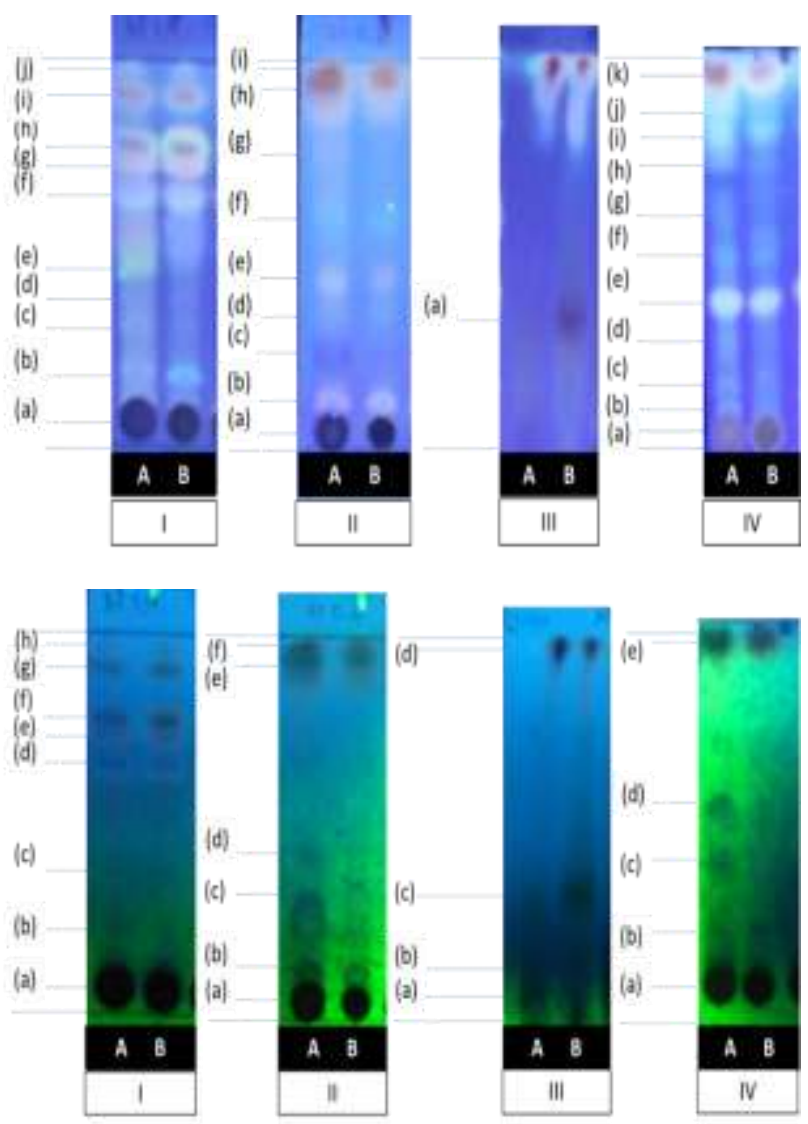

Note: I = n-hexane: ethyl acetate (1.4: 0.6); II = n-hexane: ethyl acetate $(0.6: 1.4) ; \mathrm{III}=$ chloroform: methanol $(1.6$ : $0.4) ; \mathrm{IV}=$ ethyl acetate. $\mathrm{A}=$ Cempedak samples before fermentation; $\mathrm{B}=$ Cempedak samples after fermentation

Figure 4. Thin Layer Cromatography of Mandai Cempedak (top) at $\lambda 366 \mathrm{~nm}$ (bottom) at $\lambda 254 \mathrm{~nm}$
In general, active compounds in plants are obtained by extraction using a solvent. The isomers of active polyphenol compound have a wide spectrum of solubility in different solvents. This is due to the hydroxyl group possessed by the compound differing in number and position. Extraction using a variety of solvents will produce different polyphenolic components. Polyphenol compounds presented in plants are normally extracted with methanol and ethanol. Several studies related to polyphenol compounds and antioxidant activity utilized aqua and dichloromethane, ethyl acetate, chloroform, methanol solvent mixtures, a combination of acetic acid mixtures, hexane and ether (Liu et al., 2017). The optimal use of various solvents was due to better separation of the intended compounds. This TLC phytochemical information will be used as a lead for further isolating the specific polyphenolic compounds from mandai cempedak.

\section{CONCLUSION}

Unsalted spontaneous and induced fermentation of mandai cempedak was carried out successfully. Fermentation increased the release of total phenolic, tannins, and flavonoids from mandai cempedak, which in turn positively modulated antioxidant activity. The use of starter culture resulted in higher overall phenolic substances and antioxidant activity in optimum fermentation temperature, while spontaneous LAB culture performed better to ferment mandai cempedak at sub-optimum temperature. In general, the rate of release of phenolic substances from the inner skin of fruit was halved when the fermentation was carried out at sub-optimal temperature of $8^{\circ} \mathrm{C}$. Ethyl acetate alone or in combination with $\mathrm{n}$ hexane produced better separation of the phytochemical compounds from fermented and unfermented mandai cempedak. 


\section{ACKNOWLEDGEMENT}

The authors would like to thank the Indonesian Ministry of Research, Technology and Higher Education for the PSNI research grant in 2018. This publication is a part of progress of Center of Excellence for Drugs and Cosmetics from Tropical Rain Forests, Mulawarman University, Samarinda.

\section{REFERENCES}

Bakar MFA, Karim FA, Perisamy E. 2015. Comparison of phytochemicals and antioxidant properties of different fruit parts of selected Artocarpus species from Sabah, Malaysia. Sains Malaysiana 44: 355-363. DOI: 10.17576/jsm-2015-440306.

Bakar MFA, Karim FA, Perisamy E. 2015. Comparison of phytochemicals and antioxidant properties of different fruit parts of selected Artocarpus species from Sabah, Malaysia. Sains Malaysiana 44: 355-363. DOI: 10.17576/jsm-2015-440306

Banu I, Vasilean I, Aprodu I. 2010. Effect of lactic fermentation on antioxidant capacity of Rye Sourdough and Bread. Food Technol Res 16: 571-576. DOI: 10.3136/fstr.16.571.

Curiel JA, Pinto D, Marzani B, Filannino P, Farris GA. 2015. Lactic acid fermentation as a tool to enhance the antioxidant properties of Myrtus communis Berries. Microb Cell Fact 14: 67. DOI: 10.1186/s12934-015-0250-4.

Dajanta K, Janpum P, Leksing W. 2013. Antioxidant capacities, total phenolics and flavonoids in black and yellow soybeans fermented by Bacillus subtilis: A comparative study of Thai fermented soybeans (Thua nao). Int Food Res J 20: 3125-3132.

Emmawati A, Laksmi BS, Nuraida L, Syah D. 2015. Karakterisasi isolat bakteri asam laktat dari mandai yang berpotensi sebagai probiotik. Agritech 35: 146-155. DOI: 10.22146/agritech.9 400.

Farhan H, Rammal H, Hijazi A, Hamad H, Daher A, Reda M, Badran B. 2012. In vitro antioxidant activity of ethanolic and aqueous extracts from crude Malva parviflora L. grown in Lebanon. Asian J Pharm Clin Res 5: 234-238.

Hanani E. 2014. Analisis Fitokimia. 227-229. EGC Penerbit Buku Kedokteran. Jakarta. Indonesia.
Kusumowati ITD, Sudjono TA, Suhendi A, Da'i M, Wirawati R. 2012. Korelasi kandungan fenolik dan aktivitas antiradikal ekstrak etanol daun empat tanaman obat Indonesia (Piper bettle, Sauropus androgynus, Averrhoa bilimbi, dan Guazuma ulmifolia). Pharmacon 13: 1-5.

Li X, Wu X, Huang L. 2009. Correlation between antioxidant activities and phenolic contents of radix Angelicae sinensis (Danggui). Molecules 14: 5349-5361. DOI: 10.3390/molecules 14125349 .

Liu Y, Friesen JB, Grzelak EM, Fan Q, Tang T, Durić $\mathrm{K}$, Jaki BU, McAlpine JB, Franzblau SG, Chen SN, Pauli GF. 2017. Sweet spot matching: A thin-layer chromatography-based countercurrent solvent system selection strategy. J Chromatogr A 1504: 46-54. DOI: 10.1016/j.chroma. 2017.04.055.

Malangngi LP, Sangi MS, Paedong JJE. 2012. Penentuan kandungan tanin dan uji aktivitas antioksidan ekstrak biji buah alpukat (Persea americana Mill.). J Mipa Unsrat Online 1: 5-10.

Mu'nisa A, Wresdiyati T, Kusumorini N, Manalu W. 2012. Aktivitas antioksidan ekstrak daun cengkeh. J Veteriner 13: 272-277.

Nazarni R, Purnama D, Umar S, Eni H. 2016. The effect of fermentation on total phenolic, flavornoid and tannin content and its relation to antibacterial activity in jaruk tigarun (Crataeva nurvala, Buch HAM). Int Food Res J 23: 309-315.

Nur HS. 2009. Suksesi mikroba dan aspek biokimiawi fermentasi mandai dengan kadar garam rendah. Makara Sains 13: 13-16. DOI: $10.7454 / \mathrm{ms}$ s.v13i1.350.

Nurhayati, Siadi K, Harjono. 2012. Pengaruh konsentrasi natrium benzoat dan lama penyimpanan pada kadar fenolat total pasta tomat. Indo $\mathrm{J}$ Chem Sci 1: 158-163.

Park E, Kim H, Eom SJ, Paik H. 2015. Antioxidative and anticanceric activities of Magnolia (Magnolia denudata) flower petal extract fermented by Pediococcus acidilactici KCCM 11614. Molecules 20: 12154-12165. DOI: 10.3390/molecu les200712154.

Perwiratami C, Suzery M, Cahyono B. 2014. Korelasi fenolat total dan flavonoid total dengan antioksidan dari beberapa sediaan ekstrak buah tanjung (Mimusops elengi). Chem Progr 7: 3439.

Rahmadi A, Abdiah I, Sukarno MD, Purnaningsih T. 2013. Karakteristik fisikokimia dan antibakteri virgin coconut oil hasil fermentasi bakteri asam laktat. J Teknol Industri Pangan 24:178-183. DOI: 10.6066/jtip.2013.24.2.178. 
Rahmadi A, Sabarina Y, Agustin S. 2018. Different drying temperatures modulate chemical and antioxidant properties of mandai cempedak (Artocarpus integer). F1000Res 7: 1706. DOI: 10.12 688/f1000research.16617.1.

Rahmadi A, Sari K, Sitohang S, Khoiriyah N, Handayani F, Emmawati A, Yuliani. 2017. Profil perubahan populasi BAL, $\mathrm{pH}$, kadar flavonoid, dan potensi aktivitas antioksidan dari fermentasi mandai cempedak higienis tanpa garam. Prosiding Seminar Nasional PATPI 10-12 Oktober 2017, Bandar Lampung, Lampung.
Rhee SJ, Lee JE, Lee CH. 2011. Importance of lactid acid bacteria in asian fermented foods. Microb Cell Fact 10: 1-13. DOI: 10.1186/14752859-10-S1-S5.

Valerio F, Di Biase M, Lattanzio VMT, Lavermicocca P. 2016. Improvement of the antifungal activity of lactic acid bacteria by addition to the growth medium of phenylpyruvic acid, a precursor of phenyllactic acid. Int $\mathrm{J}$ Food Microbiol 222: 1-7. DOI: 10.1016/j.ijfoodmicro.2016.01.011.

Zou Y, Lu Y, Wei D. 2004. Antioxidant activity of flavonoid rich Extract of Hypericum pertoratum L. in vitro. J Agric Food Chem 52: 5032-5039. DOI: $10.1021 /$ jf049571r. 